\title{
Evolution of Transport Policies in Latin-America, Stages and Steps Forward
}

\author{
Carlos Alberto Moncada A. ${ }^{1}$, Peter Jones ${ }^{2} \&$ Diego A. Escobar ${ }^{3}$ \\ ${ }^{1}$ Universidad Nacional de Colombia, Sede Bogotá, Departamento de Ingeniería Civil y Agrícola, Colombia \\ ${ }^{2}$ University College London, GM12 Chadwick Building, London WC1E 6BT, United Kingdom \\ ${ }^{3}$ Universidad Nacional de Colombia, Sede Manizales, Departamento de Ingeniería Civil, Colombia \\ Correspondence: Carlos Alberto Moncada A., Universidad Nacional de Colombia, Sede Bogotá, Ciudad \\ Universitaria, Edificio 214, Off. 417, Departamento de Ingeniería Civil y Agrícola, Colombia. E-mail: \\ camoncadaa@unal.edu.co/peter.jones@ucl.ac.uk/daescobarga@unal.edu.co
}

$\begin{array}{ll}\text { Received: June 8, } 2018 & \text { Accepted: June } 15,2018 \quad \text { Online Published: June 22, } 2018 \\ \text { doi:10.5539/mas.v12n7p59 } & \text { URL: https://doi.org/10.5539/mas.v12n7p59 }\end{array}$

The research is financed by Universidad Nacional de Colombia - Sede Bogotá.

\begin{abstract}
This paper presents the evolution of Latin-American transport policies in cities framed in terms of a conceptual model of three Stages recently developed to analyse policy initiatives in Western Europe cities, but probably suitable for developing countries. Stage one is identified as the accommodation of the steady growth of cars through urban road construction. Stage Two is connected to the improvement of public transport services and the shift to more efficient transport systems. Then Stage Three is based on concepts of liveable cities focused on wellbeing and social inclusion. Latin-American examples and specific cases of policy instruments' implementation are used to test the validity of this three-stage model in a South American context. Comparative data for different cities are presented, shows results and consequences in terms of congestion reduction, transport systems improvements and some early sustainable transport initiatives. The work depicts the evolving policies of some Latin-American cities, first implementing major road improvements, next the implementation of car controls, and then, the switch to improved public transport systems. Finally the implications for cities in developing countries for the upcoming challenges in transport policies are considered. The paper discusses whether there is or not a transition process in Latin-American urban transport policies, and their success and efficiency on a worldwide comparative basis. As will be shown in this paper, transport policies in Latin-American cities can be characterised in one of these identified Stages of the evolution. Some of them are in Stage Two, while others are still under the influence of caroriented planning in Stage One. Nevertheless, every policy instrument has impacts resulting from mutations in behaviour after years of application, and those impacts can make the difference between successful and unsuccessful transformations.
\end{abstract}

Keywords: transpor policy, Latin-America public transport, vehicle restrictions, transport policy evolution

\section{Introduction}

Cities all over the world are experiencing the evolution of their transport policies. Policy cycles, impacts and perspectives of transport initiatives in Latin-American cities are not far removed from the changes observed across the globe. In the 1950's the American car industry was opened up to Latin-American markets, offering the opportunity for the elites to buy a car. In the 1970's, cuts in tax barriers and the spread of car assemblers in some Latin-American countries reduced car prices, and they became affordable for the middle classes. Cities such as Buenos Aires, Caracas and México faced a rapid growth of the vehicle fleet, starting a period of motor-vehicle accommodation and the replication of the American car-oriented city model. Even though it is not possible to identify formal transport strategies at that time in those cities, some town-planning initiatives were developed to meet the needs of the steady increase of cars (Kenworthy, 2010). Investments were focused on major road improvements and vehicle-oriented land use and road layout development. Highways, rural roads and road expansions were built through privatized concessionaires who provided infrastructure and recovered their costs, and this mode of operation was significant at the end of the 1980's and the beginning of the following decade. In 
the 1990's, at the same time as the introduction of urban vehicle restriction policies to control congestion, the improvement of public transport modes and the encouragement of modal shifting were in the spotlight. The objective was the development of more efficient transport systems and the perspective of person-based transport policies instead of the vehicle-based planning. New metro lines in Sâo Paulo, Buenos Aires and Medellín, and the birth of the high capacity Bus Rapid Transit System in Bogotá, re-ordered priorities in terms of addressing users' needs instead of vehicles. Recently, the perspectives of human activity-orientation and the promotion of sustainable modes to assist in creating liveable cities have focused efforts on the reduction of motorized trips and the promotion of non-motorized modes. New initiatives of car and bike sharing, stronger barriers to private vehicle use and the requirements of integration of previously competitive transport systems are crucial. A combination of policy instruments and strong cultural changes seems to be an effective response to the increase of motorcycling and the purchase of second cars in a pro-motorized society that still uses car ownership as a measure of social status.

This paper considers whether developments in Latin-American transport policies form part of a cycle of evolution comparable to those found in many European and other post-war cities. The identification of stages of evolution and the progress of Latin-America cities, from a world-wide perspective in terms of implementing a liveable and sustainable scenario, helps to define the steps needed to move forward through comprehensive solutions that are needed urgently. In Particular, recognising that a failed policy application or the accumulation of wrong decisions, which are quite common nowadays, can affect in the long term the quality of urban life degrading the well-being and making the desired objective of attractive cities unattainable.

\section{Latin-American Transport Policies}

\subsection{The Phase of Car-Oriented Development}

The precise definition of transport policies is difficult to identify in Latin-American cities before the 1960's. Since the late decades of the nineteenth century, cities were focused on providing public transport through the creation of public bus companies in some cities of Colombia, Venezuela and Argentina. The first metro line was constructed in Buenos Aires at the beginning of the XX century. Tram-lines were developed in Lima, Sâo Paulo, Bogotá and Medellin at the end of XIX century initially with animal traction, and from the 1930's with electrical power supply. The high cost and limited availability of cars at that time restricted vehicle ownership to being the privilege of wealthy families, while middle class workers on a mainly rural continent relied on public transport. However, cities were the core places for government, economy and services. The surpluses from agricultural businesses increased the investment in urban properties and the importation of goods from Europe to decorate the cities encouraged the rise of urban economies. While Europe was in the middle of a world war in the 1940's, LatinAmerica was in a rapid process of urbanization. Most cities developed the majority of the big projects of infrastructure including main urban roads; avenues, boulevards, highways and backbone roads were defined and constructed in this decade and the next one in the 1950's. This development strategy paved the way for the caroriented development, making cars the main beneficiaries of city construction projects.

\subsection{The Spread of Vehicle Restrictions}

Policies to control urban congestion (and later improve air quality) are as long-standing in Latin-America as in Europe. While Europe had set the basis for theoretical congestion charging in the 1960s (Smeed, 1964), the first vehicle restriction started in Buenos Aires (Argentina) in the late 1970s, reducing by half the number of cars in the city-centre on weekdays, depending on the odd/even digits of the plate. Between 1979 and 1988, a similar scheme in Caracas (Venezuela) called the "Día de Parada" was introduced in the Central Business District - CBD following the same rules as the Argentinian initiative. Subsequently, more structured vehicle restrictions to reduce pollution and control congestion were implemented, and are still in operation in several high-density cities of Latin-America.

In the middle 1980's vehicle restrictions were adapted to reduce pollution. Santiago in Chile in 1986 banned the use of vehicles equipped with old technologies to alleviate emissions' peaks during winter days. A seasonal variation of vehicle restriction was applied as a control scheme during high levels of contamination and pollution. The measure was implemented as a mean of preventing exposure to high concentration of pollutants on winterdays, from April to August, and restricted the $40 \%$ of vehicles that were not equipped with a catalytic converter CC-. In 2008, the restriction in Santiago that had already been extended from March to December was combined with an additional instrument called "environmental pre-emergencies". This was a condition declared by the environmental authorities on those days when the index of pollutants reached certain threshold levels. On these days the ban covered $60 \%$ of vehicles with a CC and $20 \%$ of cars without a CC. Both restrictions were applied according to the corresponding final digit of the number plate and operated between 7:30 a.m. and 9:00 p.m. Nevertheless, it was found that those combined restrictions just reduced $9.5 \%$ of the car trips per day (De Grange 


\section{\& Troncoso, 2011).}

In 1989 the long-lasting vehicle restriction policy called "Hoy No Circula" (HNC) was introduced in Mexico City to alleviate the amount of $\mathrm{CO} 2$ emissions and protect the ozone layer. The program officially became mandatory for private vehicles in March 1990, and for public transport vehicles in January 1991. The restriction period was from 5 a.m. to 10 p.m. A similar program has also been implemented in Guadalajara, Pachuca, Puebla and Toluca. The case of Mexico City is well known as the largest permanent initiative of an environmental-oriented vehicle restriction in a major Latin-American city. Years later, Sâo Paulo in 1996 proposed a similar strategy called "Rodizio" where the removal of $20 \%$ of the vehicle fleet reduced by about $19 \%$ the annual CO emissions (Mahendra, 2008).

Some other larger cities applied similar schemes of plate numbers to control congestion in the 1990's. The city of Bogotá, in 1998, implemented the most aggressive vehicle restriction of that time for a whole urban area. The case of Bogotá is representative due to the early achievements and several stages through which the instrument developed, which was primarily used to mitigate congestion at specific peak hours. The policy was applied according to the last digit of the vehicle number plate registration, and involved the restriction of four digit groups per day, reducing by about $40 \%$ of the number of vehicles. Each car was prevented from circulating for a total of four hours on two days in a week. The scheme covered the period between 7 to 9 a.m. in the morning and between 5:30 and 7:30 p.m. in the afternoon. Soon, the morning restriction was extended to between 6:00 and 9:00 a.m. and in this format the restriction lasted for about 11 years.

In 2009, the city administration intensified the restriction. Bogota reached nearly 8.5 million inhabitants with about one million private vehicles at that time. The restriction was extended to a continuous period between 6:00 am to 8:00 p.m. affecting $40 \%$ of the registered vehicles. In 2012, the restriction changed again, returning just to the peak hours but increasing the number of restricted vehicles to $50 \%$ with the even/odd digit number of the plate. Other cities in Colombia, like Medellin in 2005, have implemented the same scheme of restriction but only for the morning and afternoon peak hours.

\subsection{The Public Transport Policy Initiatives}

After the vehicle restrictions were applied, the promotion of highly cost-beneficial urban public transport initiatives have been included in the transport policy agendas of many Latin-American governments. In the 2000's the development of new public transport infrastructures, such as large Bus Rapid Transit -BRT- systems, emulated by Asian and African cities, were acknowledged favourably as cost-effective solutions. This is the case of the Transmilenio trunk-feeder system experimented with in Bogotá. The high cost-benefit ratios in the BRT corridors make them almost as efficient as an underground system. This was based upon the concept of the Curitiba trunkline system that has operated in Brazil since 1974. After Bogotá, other cities implemented comparable public transport solutions, including Quito, Nuevo Leon in México, and Santiago.

The initiative of new transport systems had a very high political cost. The removal of traditional transport companies which had operated in Latin-American with the characteristics of free-riders, forced structural changes in society and in the development of schemes for controlling public transport operations. Planning, operation, fare collection and the overall service provision were all included as part of the structural change of the service. The needs of the system also required an institutional arrangement that replaced the traditional Secretaries of Transportation with efficient and professional Technical Institutions, companies and operators to run the system, closer to the style of Transport for London bus concessionaires.

The policy implementation not only required monetary inputs, but also investment in changing people's minds. Road space in all cities is limited and it was necessary to make a substitution of lanes that were traditionally used by private vehicles to provide exclusive lanes for the BRT corridors. Stakeholders initially rejected this reallocation; especially, traditional bus companies and private car users who saw an already congested infrastructure that would become even more constrained for their use. Competition for space requires a fundamental decision regarding policy prioritization and the importance of public transport users above vehicle needs.

Cities have been reacting more strongly to congestion and pollution. However, while European cities such as London and Stockholm used pricing as a lever and have applied congestion charges, Latin-American cities have focused on regulation and vehicle restrictions. This reflects a shift from the 1960's and 1970s' thinking, where almost all over the world vehicles were considered the most important actor on the streets. In Latin America, only thirty years later did passengers became the cornerstone of urban mobility.

\subsection{Non-Motorized Transport Policies}

As part of promoting a balanced shift towards environment-friendly transport modes to bring more sustainable 
transport and mobility systems, the promotion of alternative and non-motorized modes were first considered in some South American cities at the beginning of this millennium. Bogotá was one of the first cities to promote the improvement of bicycle infrastructure, by developing a network of cycle-paths. Nowadays, Bogotá has $313 \mathrm{~km}$ of segregated paths constructed since the 1990's. The cycle network was designed taking into account the morphology and topography of the city, and was implemented by the first administration of the Mayor Antanas Mockus (1995-1996). There are main corridors in a north-south direction in an area of relatively flat land and the west-east bound routes complete the network to connect the extremes of the periphery. There are 30 routes, of which five have a length of over $20 \mathrm{~km}$. The longest one is the Norte-Quito-Sur corridor of 26 kilometres, and all are interconnected into the nodes of the BRT system, facilitating modal interchanges for users.

Bogota has also institutionalized the 'Car-Free Day', observed on a specific Thursday every February since 2000. At this time public transport, cyclists, pedestrians and rollerblades are exclusive users of the city urban network. Police enforcement ensures the application of the initiative for the whole day on the car-free streets. This strategy has been very successful and is being replicated in several developing cities. About 1.2 million cars are left at home, and 1.5 million people travel by bicycle (Nair \& Kumar, 2005).

The "Ciclovías", Cycle-ways program has been implemented in Colombia for almost 30 years and is recognized as an initiative that promotes healthier and more active lifestyles. Cities like Belo Horizonte, Santiago, Quito and Mexico City have been implementing similar strategies since the first decade of this century (Sarmiento et al., 2010). Walkable boulevards and the restoration of places for people, by displacing car flows, have been initiatives adopted in recent times by several city administrators. Car-free city centres with cultural heritage interest are the new ideas to reactivate decayed areas and improve meeting places to attract urban life. Those initiatives can be observed in corridors such as the 7a Avenue in Bogotá, in the old town of Quito and in the old city centre of Lima.

\section{Evolution of Transport Policies: Testing the Hypothesis}

It has been hypothesised that policy changes over time can be characterized using a three-stage policy development cycle. This hypothesis has been presented recently (Jones, 2015), as a tool to understand the evolution of urban transport policies in European cities.

The model presented in Figure 1 is based on a graph structure representing the growth of vehicle ownership and car use against the different kinds of policy measures that have been introduced in recent decades in European cities. The horizontal axis represents time and covers the period approximately from the 1970's until now. The left vertical axis represents the growth of the vehicle fleet and vehicle mode share in cities. The dotted line shows the observed behaviour in a city or a region in terms of the modal share of private vehicle use. The continuous solid line reflects the policy emphasis sub-divided into three stages in terms of providing for motorised traffic, particularly cars.

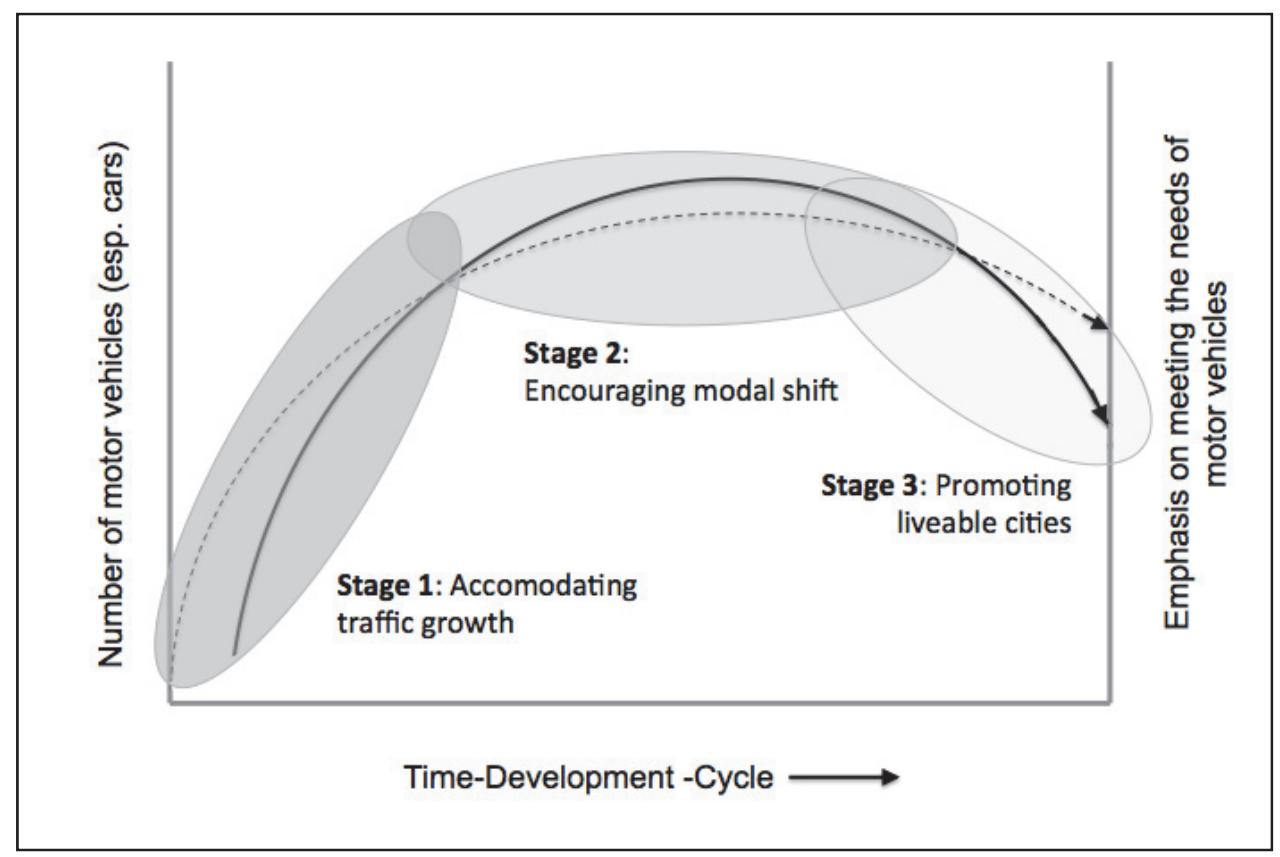

Figure 1. The urban transport policy development cycle. Source: Jones, 2014 
As can be seen, the rapid growth of the solid line in Stage One represents the accommodation of the structure of cities and their road networks to the needs of a rapidly growing private vehicle fleet. A second phase involves the promotion of policies shifting attention from private cars to personal mobility and improved public transport systems, with a consequent levelling off in private vehicle usage. Finally, the last part of the curve represents the decline of the private fleet and the reduction of trips by private motorized means, and a greater emphasis on streets as places and cities as attractive, liveable centres.

At first glance, this may seem to be an oversimplification of the evolution of transport policies in any city in the world. However, the general policy shifts that cities have encouraged through different stages, from promotion to control of private vehicles and the evolution of alternative modes can be readily observed. It can be noted in some Latin-American cities that transport policies implemented in recent years correspond with one of the three abovementioned stages. Cities like Bogota, Mexico City and Santiago have implemented for more than 20 years control policies for private vehicles. Moreover, in the last 15 years, governments have promoted the construction of public transportation systems, and today experiment with strategies to promote the use of bicycles, motorization reduction and the promotion of walking trips.

\subsection{Accommodating Private Transport}

According to this hypothesis, in Latin-America cities Stage One can be characterised as the accommodation of private vehicle ownership growth through increasing road capacity, and can be observed in the historical development of many cites. In this stage, investments were focused on major road improvements and vehicleoriented planning. With the explosion of vehicle production in the 1950's and 1960's, growing cities from developed countries faced a rapid increase of their vehicle fleet. Three crucial aspects seem to be connected to the rapid growth of motorization in recent years.

First, expansion of the automotive industry in Latin-America and the location of new assembler facilities in cities such as Mexico, Brasilia and Bogotá between the 1980's and 1990's. These factories supported very large workforces, which in turn resulted in substantial increases in domestic vehicle ownership consumption. In the 2000 's, additionally to the domestic car-production, the Free Trade Commerce agreements signed with countries such as USA and Korea reduced the price of imported cars. Second, the role of cars as mechanisms to promote a better social status in developing societies. Private vehicles are distinctive forms of consumption in LatinAmerican society, given the stratified culture in relation to social status. This culture is deeply rooted with a differentiation in people's minds that public transport is associated with belonging to the lower social classes which creates an attitude of discrimination towards those who rely on using public transport modes. And the third aspect, is the lack of competitiveness of door-to-door pubic transport travel times compared to private vehicle travel times, which contributed to the perception that individual car trips provide the most rapid and convenient mode of transport, as can be observed in databases from the Urban Mobility Observatory of CAF in 2007, as summarised in Table 1.

Table 1. Characterization of five Latin American cities in 2007

\begin{tabular}{lccccc}
\hline \multicolumn{1}{c}{ Indicators } & Bogotá & $\begin{array}{c}\text { Mexico } \\
\text { City }\end{array}$ & $\begin{array}{c}\text { Sâo } \\
\text { Paulo }\end{array}$ & Santiago & $\begin{array}{c}\text { Buenos } \\
\text { Aires }\end{array}$ \\
\hline Population (millions) & $7.5^{\text {a }}$ & 19.2 & 19.5 & $5.8^{\mathrm{b}}$ & 13.3 \\
Urban land area (km²) & 478 & 2884 & 1968 & 648 & 3883 \\
\hline Automobile fleet (millions) & 1.06 & 5.9 & 3.6 & 0.875 & 4.3 \\
Motorization rate & & & & & \\
(Automobiles/1000 persons) & 141 & 307 & 185 & 151 & 323 \\
\hline Trips per day (Millions) & 9.9 & 48.8 & 38.2 & 17.8 & 26.3 \\
Mode split of trips & & & & & \\
$\quad$ Collective trips (\%) & 57 & 52 & 33 & 36 & 40 \\
$\quad$ Individual Trips (\%) & 22 & 24 & 33 & 26 & 51 \\
$\quad$ Walking Trips (\%) & 15 & 24 & 34 & 35 & 9 \\
\hline Averag Trav
\end{tabular}

Average Travel Time (min) 


\begin{tabular}{lccccc}
\hline \multicolumn{1}{c}{ Indicators } & Bogotá & $\begin{array}{c}\text { Mexico } \\
\text { City }\end{array}$ & $\begin{array}{c}\text { Sâo } \\
\text { Paulo }\end{array}$ & Santiago & $\begin{array}{c}\text { Buenos } \\
\text { Aires }\end{array}$ \\
\hline Automobile & 40.5 & 35 & 28 & 20 & 35 \\
Motorcycle & 36 & 24 & 25 & 18 & 24.5 \\
Buses & 73 & 50 & 49.8 & 47 & 76 \\
Metro-BRT* & 95030 & 98114 & 101545 & 105940 & 113804 \\
\hline
\end{tabular}

Source: (Corporación Andina de Fomento [CAF], 2011), (Departamento Administrativo Nacional de Estadistica [DANE], 2016) ${ }^{\mathrm{a}}$, (Instituto Nacional de Estadistica [INE], 2016) ${ }^{\mathrm{b}}$

\subsection{Encouraging Modal Shift}

The inability to construct sufficient road infrastructure to accommodate the rapid growth in private cars resulted in increasing traffic congestion, and led city administrations to think in a different way: a new formulation of possible solutions to tackle congestion. Moreover, the phenomenon of motorcycle ownership as a substitution for cars became a new problem. This created a break point and led the administrations to formulate different visions of town planning, focusing on the goal of more efficient movement patterns in cities and the disincentive for using private transport. This is the start in Latin-America of the second stage of policies harmonising public transport policies and private car control. Policies of this period became focused on the movement of people instead of the mobilization of motor vehicles. The first administration of Enrique Peñalosa (1998-2000) as the mayor of Bogotá changed the paradigm of the city and turned its attention to the improvement of the public transport system. While cities such as Santiago, Buenos Aires and México City already had metro lines, the re-invention of high capacity corridors through Transmilenio has transformed the concept of quality mass transport provided by buses. In the first decade of this century, six other cities in Colombia have developed BRT systems with the possibility of express services combined with regular ones. Bogotá's system had achieved numbers close to 45,000 passengers per hour per direction, on a corridor at peak hours. It has defined a unique landmark in the world for bus systems, achieving the mobilization of passengers efficiently at a very low cost of infrastructure - at about $20 \%$ of the cost per km of a metro line - and with a financially sustainable operation.

\subsection{The Promotion of Liveable Cities}

The first oil shock and the shortage of supply, in which prices rose dramatically in the early years of the 1970's, encouraged cities for the first time to consider non-motorized modes as real alternatives for daily transport. As a consequence, in some countries like Switzerland, car-free events were launched during the year. In the Netherlands, Germany and elsewhere in Western Europe, innovators from local councils and citizens worked for the pedestrianisation of central shopping streets, and traffic calmed corridors. However, it was not until the early years of the 2000's that the balanced shifts towards providing for more environmentally-friendly transport modes. To bring a more sustainable approach to cities' development, the third stage is the perspective of human activityorientation and the promotion of sustainable modes towards liveable cities. In this stage, the efforts are based on the improvements of quality of life compared to the vehicle speed and mobility goals of the previous stages. Nevertheless, very few initiatives have yet been developed under this approach. Cycle-paths, and the experience of some cities in no-car days' initiatives in Latin-America describe the currently narrow vision about the future of liveable and walkable cities. Currently it reflects more an extension of Stage Two, to include the promotion of a wide range of non-car modes, than a full Stage 3, with an emphasis on streets as 'places' and on urban liveability and quality of life.

\section{The Outcomes of Transport Policies in Latin-America}

\subsection{Results of Vehicle Restrictions}

Below are presented the main results of the policies implemented in Latin-American cities over the last 20 years. First, the consequences of vehicle restrictions and their side effects are observed. Then, some results are presented with regard to public transport policies as well as the limited results obtained from policies more friendly to the environment, that focus on promoting liveability and social inclusion. All policies definitely have had an impact, but not all have been successful. The application of car restrictions using licence plate numbers have had numerous and unexpected impacts in Latin-American cities (Davis, 2008; De Grange \& Troncoso, 2011; Cantillo \& Ortúzar, 2014; Medina \& Velez, 2011). Such as the unintended counter-effects of the four-wheel motor vehicle restrictions, including the dramatic increase in the vehicle fleet of second cars and motorcycles in Colombian cities such as Bogotá and Medellin (Moncada \& Bocarejo, 2015). This, in turn, has resulted in a loss of quality and quantity of 
public transport (due to congestion and fewer passengers). Similarly, BRTs have built a new segregated network inside the cities, but this has resulted in huge physical urban segregation from building the large roads and barriers, isolating some districts of the cities. The second vehicle restriction in Colombia was applied in Medellín during the first half of 2005, restricting vehicles according to the last two digits of their plate during the same peak hours as Bogotá. According to National Statistics projections, Medellín had nearly 2.7 million inhabitants and more than a half million vehicles (DANE, 2016). The days of restriction per vehicle change every six months. The change implemented in the first semester of 2012 updated peak hours from 6:30 a.m. to 8:30 a.m. and from 5:30 p.m. to 7:30 p.m. It is estimated that this measure reduced movement of the private fleet by $20 \%$.

Tax barriers reductions, agreements signed with car manufacturer countries between 2000 and 2010, U.S. Dollar depreciation, and Colombia's economic progress based on commodities, boosted the growth of the car fleet with second vehicles in those cities that were affected by restriction measures. The fleet grew constantly and the rate of vehicles per inhabitant increased not only for cars but also for motorcycles.

As can be seen in Figure 2, describes the general trend in the growth of the vehicle fleet in Bogotá and Medellin between 2000 and 2012. The rate of vehicles per 1000 inhabitants has risen since 2002, and is still increasing even with the application of vehicle restrictions (See Figue 3); there is a parallel trend in the increase of vehicles until 2009 for both cities. Bogotá apparently starts to deviate once the vehicle restriction is extended and systematically applied all day long. Nevertheless, the number of vehicles per inhabitant increases constantly in Bogotá as well as in Medellin, with a higher rate for Medellin since 2005.

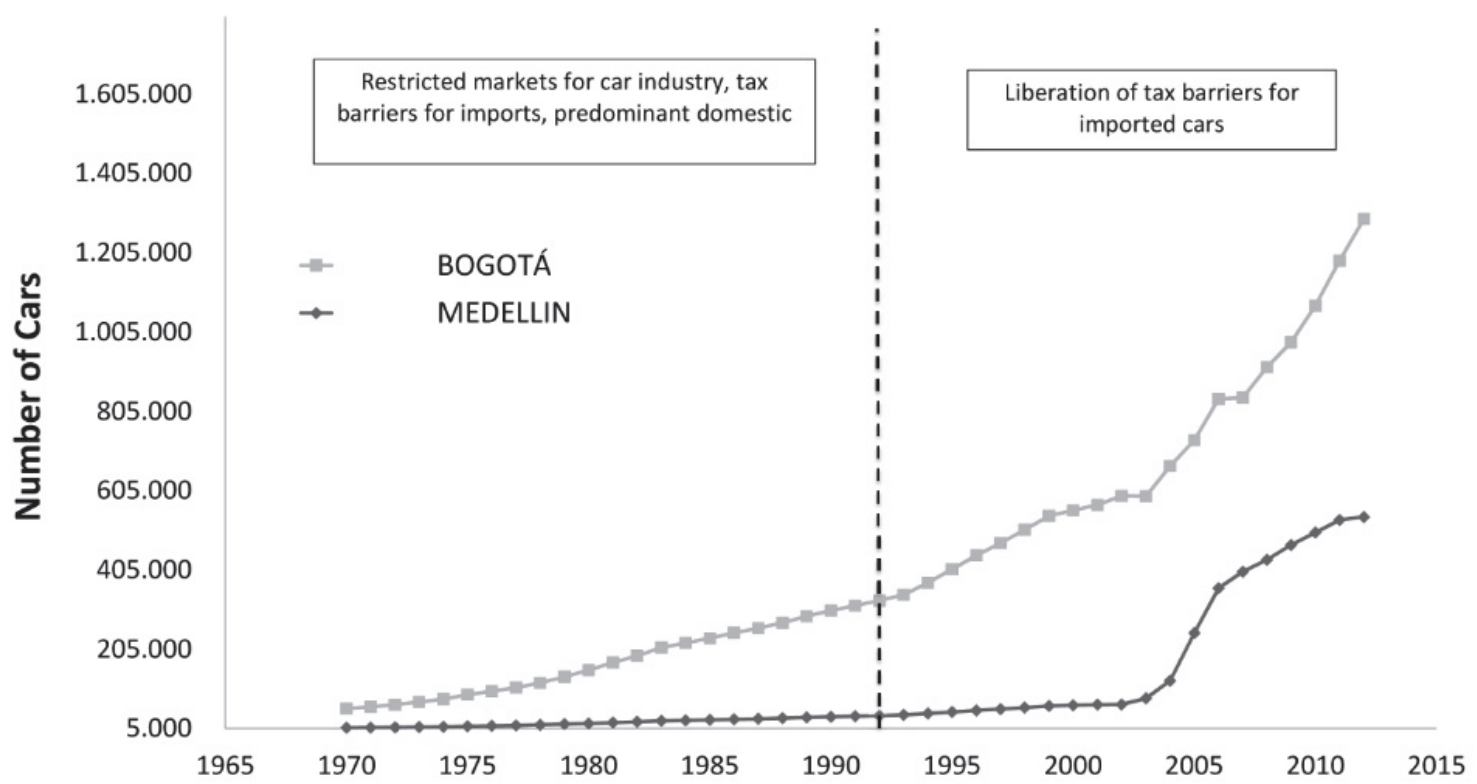

Figure 2. Evolution of private fleet Bogotá and Medellín 1970-2012. Source: SDM, and Environmental Secretary of Bogotá, 2007-2013, Medellín- Secretary of Transports, 2002, National Department of Statistics -DANE- 


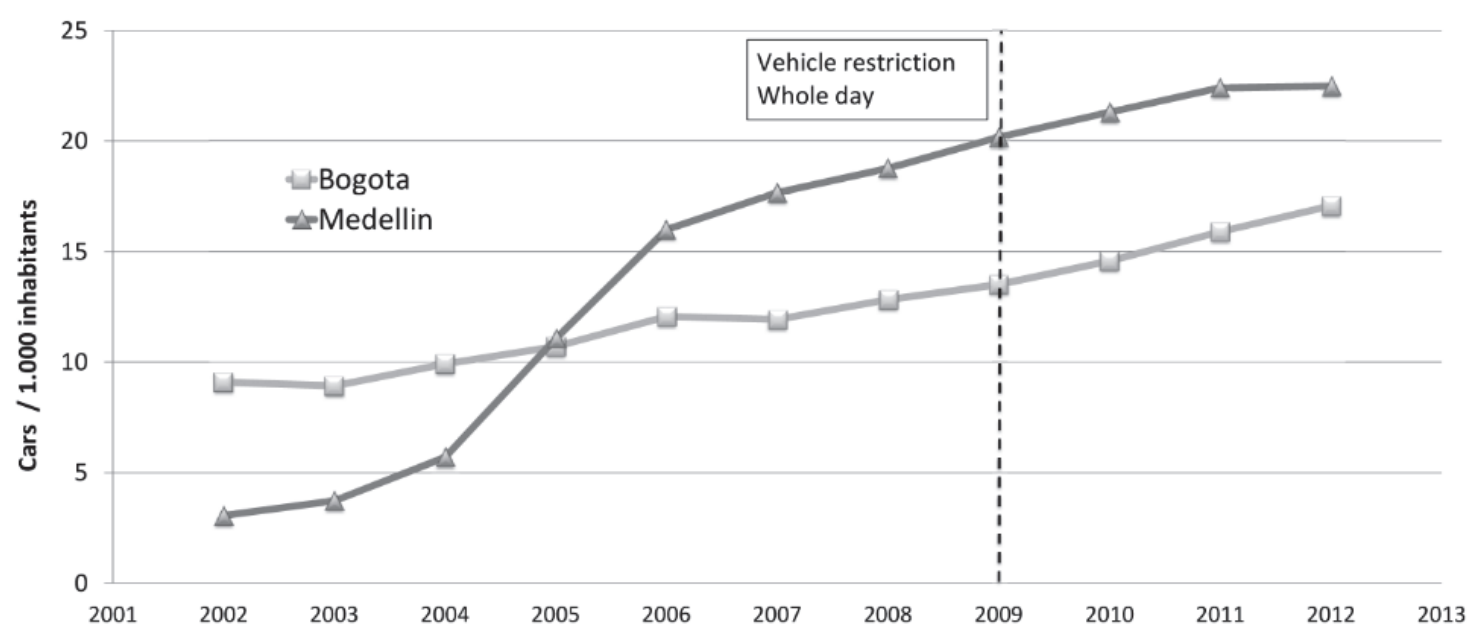

Figure 3. Evolution of cars per 100 inhabitants in Bogotá and Medellín 2002-2012. Source: SDM, and Environmental Secretary of Bogotá, 2007-2013, Medellín- Secretary of Transports, 2002, National Department of Statistics -DANE-

In Figure 4 and Figure 5, for both cities, the modal share of private transport is constant at 12-13\%, with no significant reduction of the share for private trips once vehicle restrictions were implemented. At the same time, a significant decrease in public transport modal share can be observed in the curves of both cities between 2005 and 2012. Indicating that there is no evidence that the vehicle restrictions applied in those cities have been effective; and according to previous researches, if anything they acted as counter-measures promoting the purchase of more vehicles. Findings in Bogotá (Moncada \& Bocarejo, 2015) suggest that, on average, people affected by vehicle restriction measures - such as the one implemented in the City of Bogotá - have a tendency to own $10 \%$ more vehicles - a second car or a motorcycle - compared to people living in cities who have not been affected by vehicle restrictions during the whole day. The $-\mathrm{HNC}$ - program in México City, involving a ban on drivers for one day per week, reduced the emissions from 460,000 out of 2.3 million every-day vehicles in the first year of implementation (Davis, 2008). Fuel consumption was reduced by about 11,500 gasoline barrels per day and consequently 30,000 tons of fewer pollutants per year were emitted (Secretaria del Medio Ambiente [SEDEMA], 2004). Seemingly, the primary vehicle restriction applied in Santiago is nowadays less effective than the pre-emergency strategy, due to the large number of vehicles without Catalyse Converters that are still running on the streets of Santiago. Nowadays, the majority of cars in Santiago are not affected by the vehicle restriction. As well as Mexico City, they face record levels of air pollution, following the same path as Beijing, Delhi and Milan.

\subsection{Outcomes from the Public Transport Policies}

Public transport improvement policies have had great and varied effects within the urban structures of the LatinAmerican cities. BRT systems on high capacity corridors offer an alternative to the traditional and inefficient bus companies, and there has been the development of integrated transport systems as can be found in the city of Medellin where metro, tram and BRT systems are combined. 


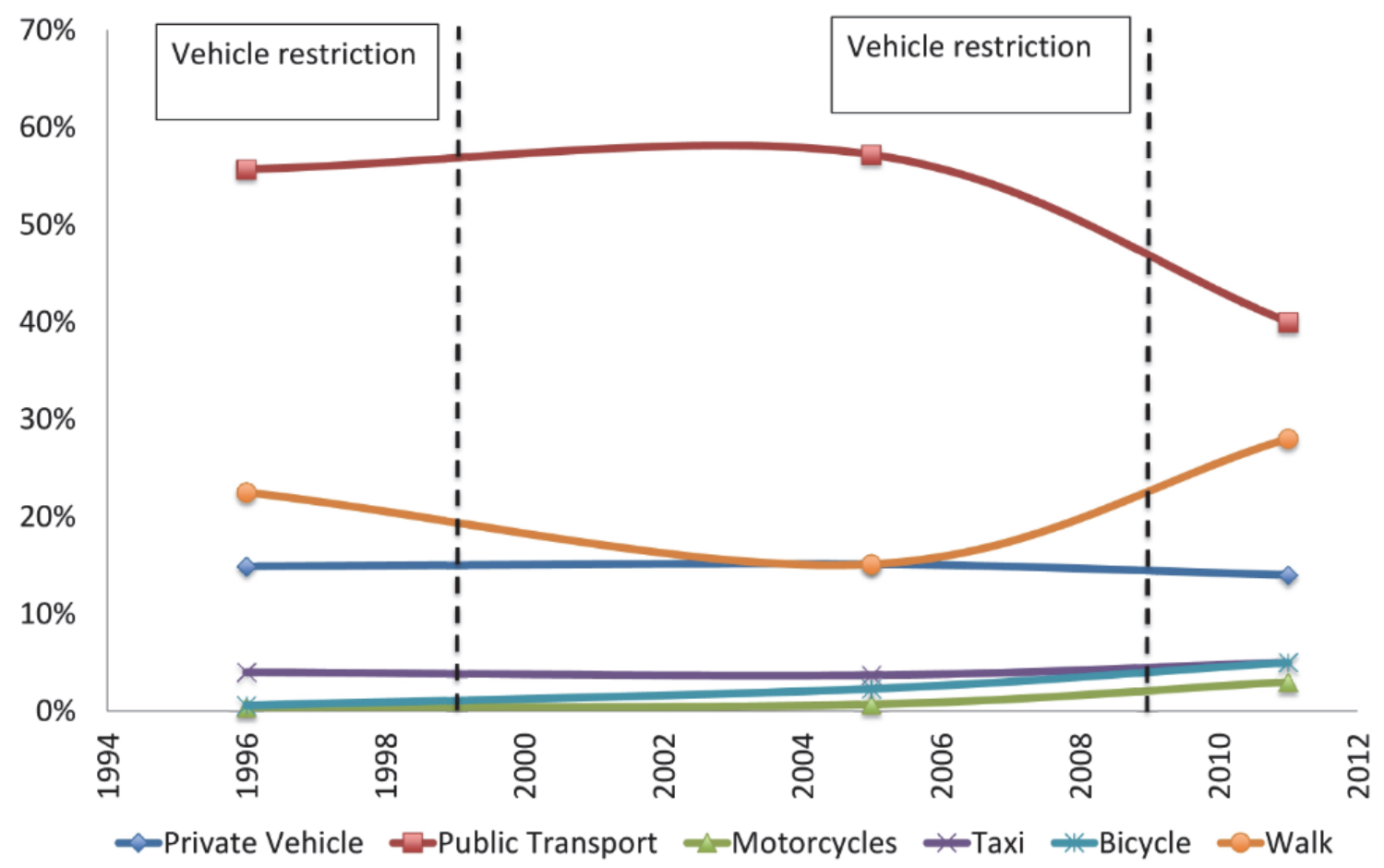

Figure 4. Modal share for Bogotá 1996-2011. Source: SDM, and Environmental Secretary of Bogotá, 20072013, Medellín- Secretary of Transports, 2002, National Department of Statistics -DANE-

The greatest success of the BRT buses operated on high capacity systems is, on the one hand the low cost of building and operating the infrastructure, and on the other an efficiency of moving passenger numbers close to the capacity of light railway systems -LRT. Exclusive bus lanes and dedicated roads produce a degree of segregation to ensure that efficient operation and scheduled services can be met, as well the target operational speeds. Stops located every $500 \mathrm{~m}$, as well as platform controls for dispatching vehicles, has allowed Bogotá to handle with their limited route BRT structure almost $25 \%$ of the total public transport demand. It is important to mention the success of this policy in Colombia and in other Latin-American cities is the result of a combination of multiple factors, including:

- The crisis of the traditional bus companies;

- Reduction of the demand for public transport;

- The high level of congestion in cities;

- The implementation of a national policy to re-organize transport systems;

- Financial instruments to carry out these policies.

Some other cities, like Quito in 1996, have operated a bus corridor with trolley buses. In 2001 they opened a second corridor "The Ecovía" and the Quito central corridor in 2005. In 2006, Santiago in Chile inaugurated the first section and backbone of its BRT-system called "Transantiago" - but with significant operational problems due to competition with the traditional companies working permanently at the side of the trunk line. This systematic error in the implementation of the policy brought substantial problems not only in Santiago but in other cities of Colombia such as Medellin and Pereira. With a correct implementation, BRT-systems can provide efficiency at very low-costs of infrastructure, as it can be seen in the comparative Table 2. 


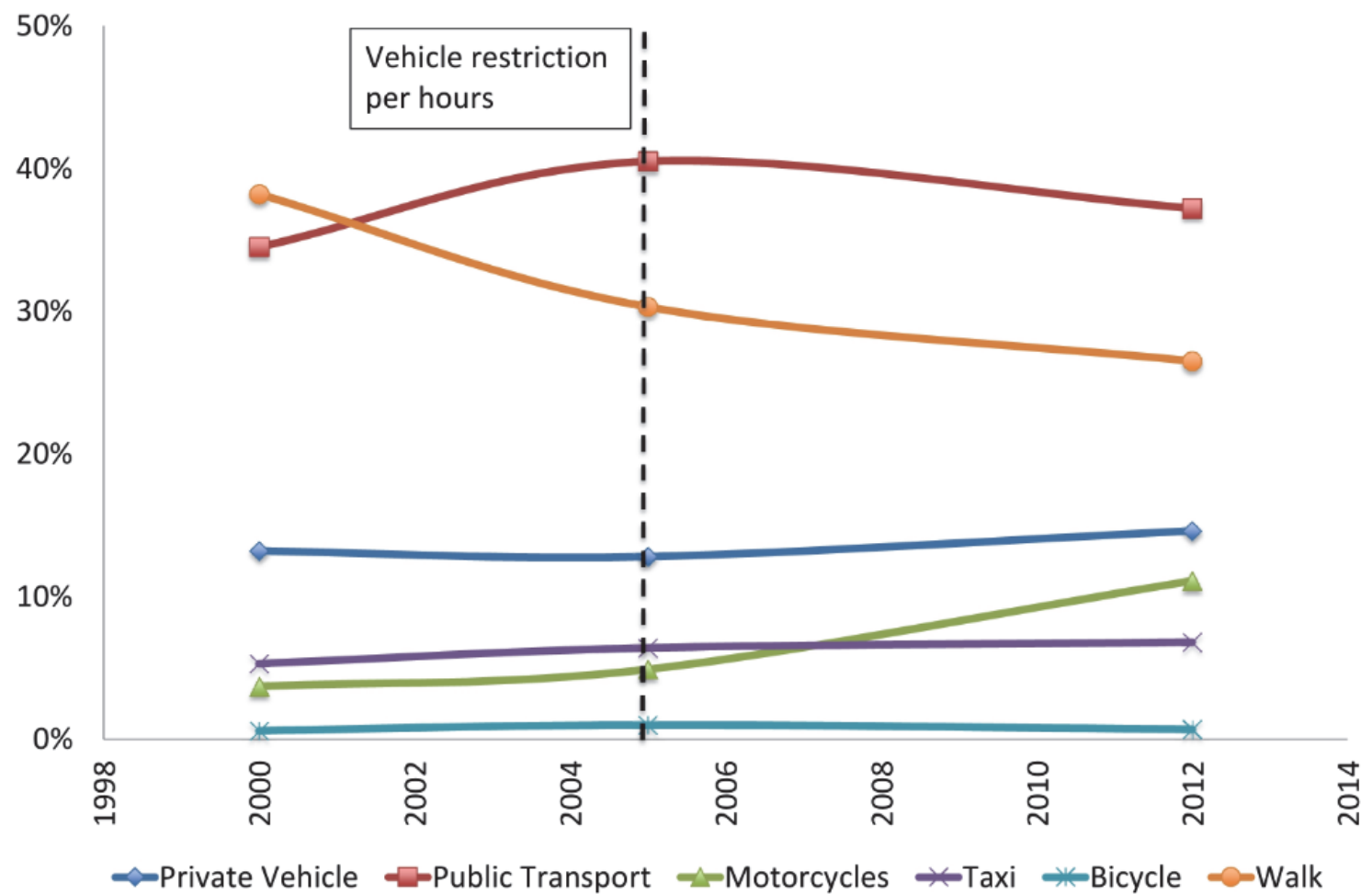

Figure 5. Modal share for Medellín 2000-2012. Source: SDM, and Environmental Secretary of Bogotá, 20072013, Medellín- Secretary of Transports, 2002, National Department of Statistics -DANE-

Table 2. Actual peak capacity in mass transit systems

\begin{tabular}{ccc}
\hline Line & Type & $\begin{array}{c}\text { Ridership } \\
\text { (pass/hour/direction) }\end{array}$ \\
\hline Hong Kong subway & Metro & 80,000 \\
\hline Sâo Paulo Line 1 & Metro & 60,000 \\
Mexico City Line B & Metro & 39,300 \\
\hline Santiago La Moneda & Metro & 36,000 \\
London Victoria Line & Metro & 25,000 \\
\hline Buenos Aires Line D & Metro & 20,000 \\
Bogotá Transmilenio & BRT & 45,000 \\
Sâo Paulo 9 de Julho & BRT & 34,910 \\
Recife Caxangá & BRT & 29,800 \\
Porto Alegre Assis Brasil & BRT & 28,000 \\
\hline Belo Horizonte Critiano M. & BRT & 21,100 \\
Curitiba Eixo Sul & BRT & 10,640 \\
Manila MRT-3 & Elevated Rail & 26,000 \\
Bangkok Sky Train & Elevated Rail & 22,000 \\
Kuala Lumur Monorail & Monorail & 3,000 \\
\hline
\end{tabular}

Source: Wright and Hook, 2007.

The success of the policy based on trunk lines for buses supported the strategy of an emergent transit oriented development (TOD) land use planning in Latin-America. While most metro systems require long construction 
periods and large planning phases, BRT systems have been constructed in shorter times and smaller implementation horizons. While a BRT corridor of $40 \mathrm{~km}$ can be built in three years, $16 \mathrm{~km}$ of metro line requires 3 to 5 years to be built. The success of the policy requires a series of components to be coordinated - operational, financial and technical - to make the project an efficient system.

Public transport systems have the potential to cause transformations within cities, to improve patronage and revenues, and increase land prices when developing strategies to meet the demand of users. However, it is important to mention that rail systems are still more efficient due to the fact that they are completely segregated from road traffic, unlike BRT. The problem with the operation of buses arises when they are subject to traffic light control. The trunk bus line, despite its efficiency, depends more heavily on the traffic situation and is adversely affected by the saturation of intersections and limited capacity of the stations to a much greater extent than rail systems.

\subsection{Outcomes from the Non-Motorized Strategies}

Policies to build friendlier cities for citizens are barely emerging in Latin-America. The analysis of indicators such as well-being, safety and efficiency for a friendly life in the cities are not targets of research and are still much less valued by the city administrations. Social equity is still relatively unexplored in Latin America compared to the objectives of faster systems and economic growth. Major efforts such as promoting bicycles, motorized trip reduction; environmental sustainability, liveability and quality of urban place are objectives that are still in their infancy. The network of cycle-paths is a breakthrough in Bogota, as well as the development of some days without cars in the main cities of Colombia. This effort can be compared with the policies developed in Copenhagen and Amsterdam trying to promote bicycles several decades previously. However, policy change and changes in users' minds will require cultural efforts around promoting the bike and recolonising public spaces, in order to implement such policies by future governments. Important political achievements in non-motorized transport, such as the increase of about $100 \%$ in bike trips, can be observed when comparing the household transport surveys for Bogota between 2011 and 2015. A large group of people are using walking and cycling not only as a secondary access means of transportation but also as principal ones. Unfortunately, as yet these successes are scarcely emerging in other Latin American cities, where the implementation of the Car-free and motorcycle free-days and strategies of cycle-ways during weekends and holidays for recreational purposes are rarely to be seen.

\section{Are Urban Transport Policies in Latin-America Part of an Evolving Progression of Events?}

As can be seen from this analysis, Latin-American urban transport policy development can broadly be framed along the lines proposed by Jones (2015). Without having clearly articulated a comprehensive urban transport policy at that time, it is possible to conclude that the governments of Latin America between the 1950's and the 1980 's planned the construction of urban roads, parking lots and the configuration of a vehicle-oriented way of life. The expansion of urban boundaries, the increase of roads' kilometres per capita and developments in the city borders in the form of suburbs, enable us to recognize in Latin-America the same trend as happened in Western Europe, but extended over a much longer time period and finishing almost 20 years later. At the end of the 1990's a typical Latin-American city was still in the first stage of the policy development.

The disproportionate increase in the private fleet, the economic growth in the first decade of this century and the awareness of extreme levels of congestion and air pollution in developing countries forced the reformulation of policies and the shift to investment in new public transport systems. It is possible to identify that by the end of the 1990 's it was a concern of city governments in Latin-America to control private vehicles for good reasons such as congestion or air quality. These coordinated strategies within the city management were instruments that suggest the idea of moving to a Stage Two, by shifting from car provision to a substitution in modal shares. Arguably, policies that were formulated, regardless of their success, can be framed as coordinated policies in the first decade of 2000's to promote public transport and to control private vehicles. Probably most of Latin-America cities are located at this intermediate Stage: developing systems with more efficient public transport systems but with no clear visions for the future of cities and still fighting to stabilise and decrease the car fleet. The probable curve that best identifies the stages of the policies in Latin-America is shown in Figure 6, where the dotted line represents the continuing increase of the vehicle fleet, in spite of the efforts to control vehicle use and the promotion of modal shifting.

The sustainability of transport modes, welfare and quality of life improvements are only recently emerging concepts in Latin-American cities, which are still more focused nowadays on providing speed and efficiency. While the car remains a mechanism used by a minority of users, it still has influence and conceptually remains a social differentiator and a symbol of status. Focusing on well-being and social inclusion makes cities more equitable and pleasant to inhabit, involving modern paradigms of new cultural approaches. That should be in the 
spotlight of city administrators' visions, not only in the discussion of developed countries, to construct a more equal and healthier Latin-American society.

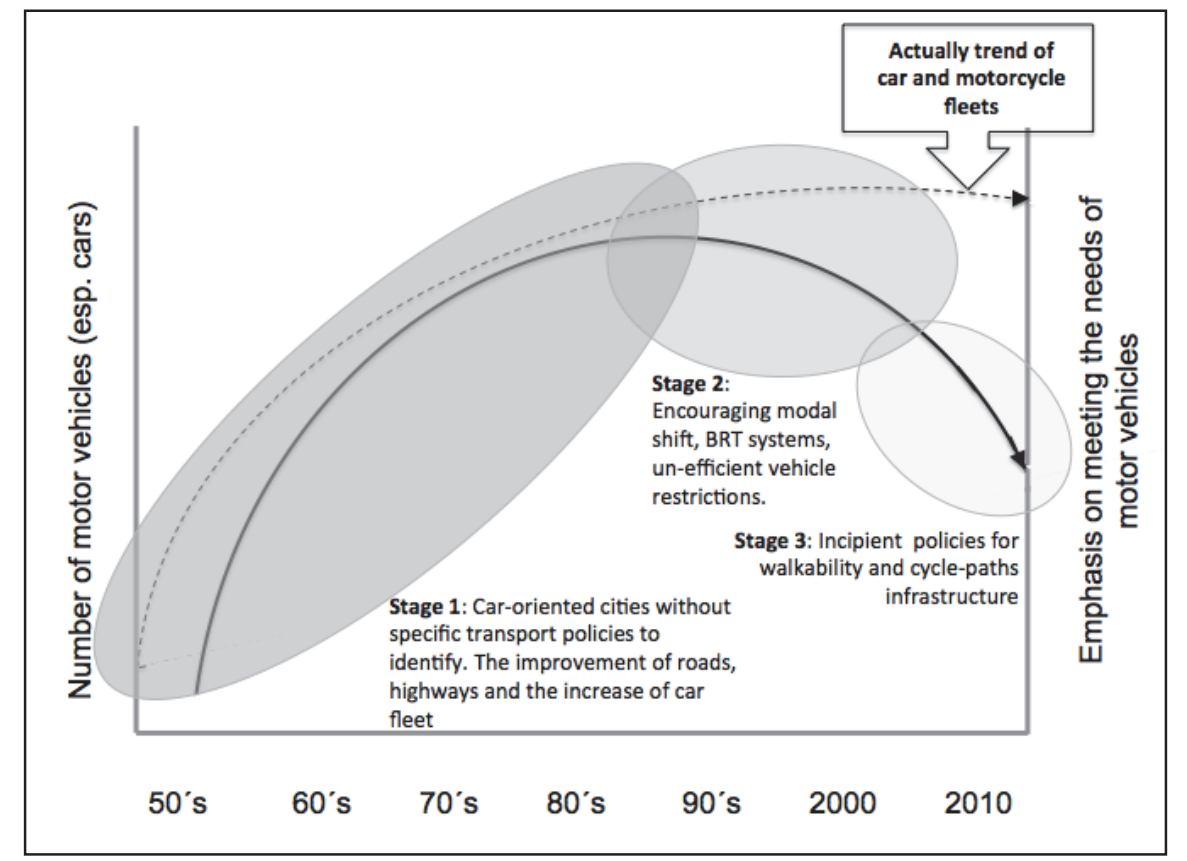

Figure 6. Characterization of the urban transport policy development in Latin-America

\section{Conclusions}

As has been shown, urban transport policy over the past 60 years in Latin America can be seen as a set of initiatives that responded to a series of changes that decisively have affected the transport networks and land use patterns of cities. The decline of public transport systems in the 1980's and 1990's, following decades of road construction, added to the growth of the car fleet and gave birth to schemes of vehicle control policies. Unfortunately the vehicular restrictions, as they have been introduced, have not been efficient or effective as tools to control private vehicles, and probably instead of meeting their objectives have just promoted an increase in the size of the cities' vehicle fleets.

Public transport policies have had a greater success, with BRT providing an efficient and inexpensive solution. They have been able to meet the needs of cities and have become global models to imitate. A new paradigm for transport systems built on bus corridors developed in Latin America has proved to be an efficient low-cost solution. Nevertheless, once capacity is reached, and more than 30,000 passengers per hour are required to be transported, railway systems provide the best solution to transport such volumes of users. BRT systems allowed cities in LatinAmerica to combine efficient mobilization and prioritization to replace private transport strategies, but only up to a certain capacity limit.

It might be considered that urban transport policies in Latin America are very distant from the developed world. However, as they have been presented here, they largely follow the sequential phenomenon (at least from Stage One to Stage Two) as has been hypothesised, albeit with some variations in the time of occurrence. The progression between stages has probably been slower in Latin America, but cities today have been led to a combination of more aggressive and more effective policies with respect to private vehicle restrictions and the support of enhanced public transport systems. Vehicle restrictions based on regulation seem to have been inefficient and produce few revenues, and should perhaps be replaced by mechanisms of congestion charges or urban toll roads.

The reluctance to limit car ownership and use - and the 'prolonged' period in Stage One - in Latin-America could be due to two sets of factors that should be explored further:

- Average door-to-door speeds by car and motorcycles versus public transport to major centres may not be roughly the same, which seems to be a condition to limit growth in motor vehicle use (i.e. BRT cannot provide as attractive door-to-door speeds as more reliable metro systems can, as it was presented in Table 1) 
- Car ownership is still at the top of the personal investment priorities of medium and higher social classes of the population - it is still seen as an elite good - so people are not yet willing to stop striving to own one. For lower income people, the motorcycle's affordability is providing them with access to personal transport and leading to a more dramatic increase in motorization.

The future evolution of transport policies in Latin-American cities would be to construct sustainable cities based on reducing motorized trips, improving the liveability and the quality of life, and supporting efficient public transport systems, as primary challenges if cities wish to follow Western Europe and are to move from Stage Two to Stage Three.

\section{Acknowledgments}

Thanks to the research group PIT at Universidad Nacional de Colombia for their assistance and support in different stages at this PhD research. To Professor Peter Jones for his dedication, his critical and helpful comments to improve this work, and outstanding guide as a $\mathrm{PhD}$ advisor, where this paper is one of the main chapters.

\section{References}

Cantillo, V., \& Ortúzar, J. D. D. (2014). Restricting the use of cars by license plate numbers: A misguided urban transport policy. DYNA, 81(188), 75-82. https://doi.org/10.15446/dyna.v81n188.40081

Corporación Andina de Fomento - CAF (2011). Desarrollo urbano y movilidad en América Latina, Observatorio de Movilidad Urbana.-CAF Dirección de análisis y Programación Sectorial, ISBN: 978-980-6810-55-6.

Davis, L. W. (2008). The Effect of Driving Restrictions on Air Quality in Mexico City. Journal of Political Economy, 116(1), 38-81. http://doi.org/10.1086/529398

De Grange, L., \& Troncoso, R. (2011). Impacts of vehicle restrictions on urban transport flows: The case of Santiago, Chile. Transport Policy, 18(6), 862-869. http://doi.org/10.1016/j.tranpol.2011.06.001

Departamento Administrativo Nacional de Estadistica, Colombia - DANE (2016). Proyecciones censo general 2005. Retrieved from http://www.dane.gov.co/index.php/poblacion-y-demografia/censos

Instituto Nacional de Estadistica, Chile, INE (2016). Proyecciones censo general 2012. Retrieved from http://www.ine.cl/canales/chile_estadistico/familias/censos.php

Jones, P. (2014). The evolution of urban mobility: The interplay of academic and policy perspectives. IATSS Research, 38(1), 7-13. http://doi.org/10.1016/j.iatssr.2014.06.001

Jones, P. (2015). Long-term Trends in Urban Transport Policy Development in Advanced Western Cities - a model with wider application? Working paper.

Kenworthy, J. (2010). An International Comparative Perspective on Fast Rising Motorisation and Automobile Dependence in Developing Cities, in Dimitriou, H. and Gackenheimer, R. (ed), Urban Transport in the Developing World: Persepectives from the First Decade of the New Millennium. pp. 71-112. United Kingdom: Edward Elgar.

Mahendra, A. (2008). Vehicle Restrictions in Four Latin American Cities: Is Congestion Pricing Possible? Transport Reviews, 28(1), 105-133. https://doi.org/10.1080/01441640701458265

Medina, C., \& Velez, C. (2011). Aglomeración económica y congestión vial: los perjuicios por racionamiento del tráfico vehicular. Borradores de Economía, Banco de La República, Colombia, 678, 55.

Moncada, C. A., \& Bocarejo, J. P. (2015). Application of a methodology to assess policies to control private vehicle traffic in cities. Proceedings of CODATU XVI, Climate change, air quality and energy challenges, 2-5 February 2015, Istambul, Turkey (P. 14).

Nair, P., \& Kumar, D. (2005). Transformation in Road Transport System in Bogota: An Overview. The ICFAI Journal of Infrastructure, $\quad$ (September), 20-28. Retrieved from http://econwpa.repec.org/eps/urb/papers/0508/0508005.pdf

Sarmiento, O., Torres, A., Jacoby, E., Pratt, M., Schmid, T. L., \& Stierling, G. (2010). The Ciclovía-Recreativa: A mass-recreational program with public health potential. Journal of Physical Activity \& Health, 7 Suppl 2(Suppl 2), S163-S180. $\quad$ Retrieved from https://pdfs.semanticscholar.org/45c9/a4d435e75ce9e8c6e5a1f943b16ac6279e06.pdf

Secretaría del Medio Ambiente - SEDEMA. (2004). Dirección General de Gestión de la Calidad del Aire, Ciudad de México. Retrieved from http://www.aire.df.gob.mx/default.php?opc=\%27aqBjnmI=\%27

Smeed, R. J. (1964). Road Pricing: The Economic and Technical Possibilities. London, Ministry of Transport, 
Report HMSO. Retrieved from https://archive.org/details/op1265810-1001

Wright, L., \& Hook, W. (2007) Bus Rapid Transit Planning Guide, Institute for Transport and Development Policy ITDP, New York.

\section{Copyrights}

Copyright for this article is retained by the author(s), with first publication rights granted to the journal.

This is an open-access article distributed under the terms and conditions of the Creative Commons Attribution license (http://creativecommons.org/licenses/by/3.0/). 